\title{
EXPERIENCE OF THE INPUT-OUTPUT MODELS APPLICATION TO THE MOLDOVAN ECONOMY
}

\section{Elvira NAVAL1, Doctor of informatics, Coordinating Researcher, Institute of Mathematics and Computer Science “Vladimir Andrunachievici”, Republic of Moldova}

The main goal of this article is to present an overview of the input-output models which have been applied to Moldovan economy development study. We examined: static input-output model, dynamic inputoutput model restricted by limited energy resources, and the Markov chain approach based on the inputoutput tables. All these models have been examined using statistic data referring to the input-output table, constructed on the base of 19 and 16 aggregated branches of the national economy. Static and dynamic optimization models were formulated, simulation calculation was done and analysed. Input-output table balancing problem was solved using RAS method. For dynamic model matrix of the investment coefficients was constructed. The emphasis was put on the problem of applying the theory of Markov chain for examination of the 19 and 16 branches in the framework of the input-output model for Republic of Moldova. A square exchange matrix of order $n \times n$ has been constructed. Every branch was considered as one state of the Markov chain with $n$ states. We introduced a new $(n+1)$-th absorption state so that the examined matrix became of the order $(n+1) \times(n+1)$. The obtained transition matrix-probabilities matrix has been used for forecasting.

Keywords: input-output models, static optimization model, dynamic optimization model, Markov chain, exchange matrix, investment matrix, transition matrix, forecasting.

Obiectivul principal al acestui articol constă în prezentarea unei sinteze asupra modelelor interramurale utilizate în studierea dezvoltării economice a Moldovei. Au fost examinate modelul de optimizare static şi modelul de optimizare dinamic restricţionat de resurse energetic limitate, la fel şi abordarea stocastică bazată pe lanţurile Markov, obţinute în baza tabelelor intrări-ieșiri. Modelele menţionate au fost dotate cu date statistice în vederea construirii tabelelor intrări-ieșiri, având la bază 19 şi 16 ramuri agregate ale economiei naţionale. Modelul static şi modelul dinamic de optimizare au fost formulate, calculele de simulare în baza lor au fost efectuate şi analizate. Problema balansării tabelelor intrări-ieşiri a fost soluţionată prin aplicarea metodei RAS. Pentru modelul dinamic s-a construit matricea coeficienţilor investiţionali. Accentul a fost pus pe problema aplicării lanţurilor Marcov la examinarea a 19 şi 16 ramuri în cadrul modelului intrări-ieşiri pentru Republica Moldova. Matricea pătrată a cheltuielilor materiale directe de ordinul $n \times n$ a fost construită. Fiecare ramură fiind considerată ca o stare a unui lanţ Markov cu n stări. A fost adăugată o stare absorbantă încât matricea de tranziţie s-a transformat într-o matrice de ordinul $(n+1) \times(n+1)$. Matricea de tranziţie obţinută - matricea de probabilităţi, s-a folosit în scopuri de previziune.

Cuvinte-cheie: modele intrări-ieşiri, model de optimizare static, model de optimizare dinamic, lanţuri Markov, matricea cheltuielilor materiale directe, matricea investiţională, matricea de tranziţie, previziune.

Главная цель настоящей статьи заключается в предоставлении обзора межотраслевых моделей, используемых для изучения экономического развития Молдовы. Были рассмотрены оптимизационная статическая модель и динамическая модель с ограничениями на энергетические ресурсы, а также стохастическая модель, основывающаяся на цепях Маркова, построенных на основе таблиц затраты-выпуск. Рассмотренные модели были снабжены статистическими данными, необходимыми для построения таблиц затраты-выпуск по 19 и 16 агрегированным отраслям национальной экономики. Были сформулированы статическая и динамическая оптимизационные модели, по которым были проведены и проанализированы имитационные расчеты. Таблицы затраты-выпуск были сбалансированы с помощью метода RAS. Для динамической модели была построена матрица коэффициентов инвестиционных затрат. Основной акцент был поставлен на применение Марковских цепей для изучения 
19 и 16 агрегированных отраслей в рамках модели затраты-выпуск для Республики Молдова. Каждая отрасль ассоциировалась с одним из состояний цепи Маркова с $n$ состояниями. К рассматриваемой цепи добавилось еще одно, абсорбированное состояние так, что переходная матрица приобрела порядок $(n+1) \times(n+1)$. Построенная переходная матрица - вероятностная матрица была использована в целях прогнозирования.

Ключевые слова: модели затраты-выпуск, статическая оптимизационная модель, динамическая оптимизационная модель, цепи Маркова, технологическая матрица, инвестиционная матрица, переходная матрица, прогнозирование.

DOI: https://doi.org/10.36004/nier.es.2019.1-03

JEL Classification: C61, C68

UDC: 330.45

Introduction. For empirical applications, the input-output table has the same importance as a mathematical model. Most analyses start from tables in money units and devote a great deal of effort to making sure that the total money value of each row is equal to that of the corresponding column before deriving a coefficient matrix. By contrast, Leontief [1-4] stressed the technological interpretation of each column of coefficients and urged the collaboration of economists with engineers and other technological experts to project, column by column, coefficient matrices representing hypothetical changes in technologies in different industries based on the information in physical units.

Scientific approach is based on the modeling modern theory, relied on the input-output tables approach. Interbranch models are made up from matrices of direct material expenditure of one producing industry for other producing industries. Method for interbranch balances construction has been proposed and implemented by Russian scientist Vasilii Leontief [1-2]. In the year $1972 \mathrm{~V}$. Leontief was awarded the Nobel Prize in economic science "for elaboration of the input-output method and its application for solving important economic problems". In time interbranch models passed through spectacular evolution, being studied both deterministic and stochastic models; static and dynamic models with lagged capital investment (one or more years), simulation and optimization models. Interbranch models are largely applied to economic development examination taking in account environmental medium. Such models have been used for world and regional economy evaluation, as a forecasting and indicative planning tool for medium and long term. Now these models are used in many industrial developed countries, but also in some less developed countries.

The purpose and scientific basis of the research

The present research deals with the overview of author`s research experience in the interbranch modeling and the last research related to the Markov chain applications relied on input-output table. They studied deterministic static [6-8] and dynamic [9-10] optimization models, general equilibrium models, stochastic models [11]. Empirical researches, simulation calculations and obtained results analysis have been effectuated. Father, general theory of the input-output models will be followed [18].

Scientific basis of the research is the input-output Leontief model [4], which consists of ${ }_{n}$ industries $1,2, \ldots, n$. The $i$ - th industry requires an amount $0 \leq a_{i j} \leq 1$ of goods (in physical units) from industry $j$ to produce 1 dollar's worth of goods. The external demand for the industries goods, in physical units, is given by the vector $y=\left(y_{1}, y_{2}, \ldots, y_{n}\right)$.

Let $A$ be the (nxn) matrix of inter-industry coefficients $a_{i j}$, the industries produce total amounts given by the vector $x=\left(x_{1}, x_{2}, \ldots, x_{n}\right)$ and $F$ is the matrix ( $k x n$ ) of factor input per output (one row for each factor), and $f$ is total factor use. Then the basic static input-output model looks as: $(I-A) x=y$, or

$$
\begin{aligned}
& x=(I-A)^{-1} y \\
& f=F x .
\end{aligned}
$$

The amounts of goods which the industries will need just to meet their internal demands, is given by the vector $x A$. In order to meet the external demand $y$ and the internal demands the industries must produce total amounts given by a vector $x=\left(x_{1}, x_{2}, \ldots, x_{n}\right)$. which satisfies the equation $x=x A+y$.

The inverse matrix $(I-A)^{-1}$ has been called the Leontief inverse, also known as the multiplier matrix or matrix of multipliers. 
Equations (1) and (2) are a quantity input-output model, and the coefficients in $A$ and $F$ matrices are ratios of physical units. If $y$ is given, the solution vector $x$ represents the quantities of sector's outputs.

Assume that each industry's output is measured in a unit appropriate for that sector. A mixed-unit flow table accommodates variables measured in different units and can be constructed with no conceptual difficulty. In the coefficient matrix $A$ derived from such a flow table, the $i j-t h$ element is equal to the $i j_{t h}$ element of the flow table divided by the $i j_{t h}$ row total. So, mixed unit $A$ matrix may be constructed as columns of coefficients.

Equations (1) and (2) represent an abbreviation of the basic input-output model. The full model involves two additional equations (where (.)' indicates transposition):

$$
\begin{aligned}
& p^{\prime}(I-A)=v^{\prime}=\pi^{\prime} F \quad \text { or } \\
& p^{\prime}=v^{\prime}(I-A)^{-1}=\pi^{\prime} F(I-A)^{-1} \\
& p^{\prime} y=v^{\prime} x=\pi^{\prime} F x
\end{aligned}
$$

Here, $p$ is the vector of goods unit prices, $v$ is value-added, the total money value of factor inputs per unit of output, and $\pi$ is the vector of factors prices.

Equation (4), called the income equation, is derived from Equations (1) and (3), the GDP identity assures that the value of final deliveries is equal to total value-added

The Leontief inverse is strictly positive, i.e., each element is positive. It follows from basic economic logic which requires that an increase $\Delta y>0$ in final demand in Equation (1) should result in an increase $\Delta x>0$ in total output. If the matrix $(I-A)^{-1}$ was not strictly positive, this logic could be violated. In consequence, Equation (1) always has a solution $x>0$ for $y>0$. There are a number of equivalent statements about $A$ :

1. $(I-A)^{-1}>0$.

2. $(I-A)^{-1}=I+A++A^{2}+A^{3}+\ldots$ (The series $\sum A^{k}$ is convergent).

3. The successive principal minors of $(I-A)^{-1}$ are positive.

4. There exists a choice of units such that all row sums or all column sums of $A$ are smaller than unity.

5. The matrix $A$ has a dominant eigenvalue $\lambda, 0<\lambda<1$.

6. A dominant eigenvalue $\lambda$ of $A$ is larger if one element of $A$ is increased, and $\lambda$ gets smaller if one element of $A$ is decreased.

Statement 2 is important for distinguishing the industries contributing output in different phases of production. It says that output $x=y+A y+A(A y)+\ldots$ So the quantity y must be produced, plus $A y$ which is the vector of input to produce $y$, etc. Statement 3 is the well-known Hawkins-Simon condition, which assures that each subsystem is productive; that is, each subgroup of industries $i, j, k, \ldots$ requires less input from the economic system than it produces in terms of outputs. According to statement 4 , the Brauer-Solow condition, value-added in each sector is positive in coefficient matrices derived from inputoutput tables in (nominal) money values. Assuming that the matrix describes a viable economy, this property assures that if output is measured in any chosen physical units, there exists a set of prices such that each industry has a positive value-added (i.e., revenue left to pay for factor inputs).

The dominant eigenvalue $\lambda$ is a measure of the size of the intermediate outputs produced in the economy relative to total production. That is, $\lambda$ indicates the net surplus of an economy in the sense that the larger $\lambda$ (within the bounds described by statement 5), the smaller the net output. The surplus so defined can be consumed, invested for growth, devoted to environmental protection, etc. Statement 6 is useful for interpreting the role of technological change. For example, a technological innovation that reduces the need for certain intermediate inputs results in a lower dominant eigenvalue for the new coefficient matrix, leaving more surplus. Innovations that are not cost-reducing, on the other hand, will result in a larger $\lambda$. Input-output analysis can effectively identify those industries where increased technological efficiency would have a significant economy-wide impact. Thus, $\lambda$ is a kind of efficiency indicator in that of two matrices describing two different economies, the one with a larger dominant eigenvalue represents the economy that is less efficient economically although it may have other desirable features. Eigenvalues also play an important role in dynamic models, where they have an interpretation 
in terms of rates of growth or contraction and profit rates. If the economy does not produce a surplus (i.e., $y=0$ in Equation (1)), we deal with a closed model of the following form $x=A x$.

In this special case, $A$ has a dominant eigenvalue equal to unity, and total output $x$ is the PerronFrobenius eigenvector of $A$. To solve this model for $x$ means to solve it for this eigenvector. The solution provides only the production proportions; the scale has to be determined in other ways, such as external knowledge about the size of certain elements of $x$.

Above we interpreted the $i_{t h}$ column of the input coefficient matrices $A$ and $F$ as representing the technology to make good $i$ and claimed that the coefficients represented an average technology. This interpretation allows for the existence of differences in technology among enterprises in the same industry. The use of an average avoids the complication of having to distinguish products and technologies where the distinction does not add much useful information for the purposes of the analysis. In terms of the model, it means that a one-to-one relation is established between the typical commodities and also average technology for producing it.

Suppose a new technology becomes available to produce the $i-t$ good. The $i_{t h}$ columns of $A$ and $F$ will also be balanced if the new technology is adopted by this industry. If two technologies are available for producing the $i_{t h}$ good, the model can determine which technology is the lower-cost choice in terms of the overall use of factors. Equation (3) shows that the cost of factor use is equal to $v^{\prime} x$ or $\pi^{\prime} F x$. If the new technology is cheaper in terms of overall factor inputs, it is more efficient than the old one and in principle will be installed. Because each price is the sum of the costs of the primary resources used directly and indirectly in its production, introducing the new technology will assure minimal cost.

These considerations enable to formalize the economically most efficient choice of technology as a minimization problem. The non-substitution theorem formulated and proved in [7,9] identifies the choice among several alternative technologies that minimizes the use of priced resources for each product. It can be shown that for a particular final demand $y$, there is a unique, cost-minimizing set of technologies, provided that the possibility of factor constraints is ignored.

There are three types of impact, propagated through economy: direct, indirect, and induced that could be estimated by input-output models. Economy wide shocks deal with changing in the initial expenditure. Impact of the input changing between industries contributing to modifications in one or more specific technologies can be estimated.

Data sources and utilized methods

Direct material expenditure coefficients matrices were constructed on the National Accounts base in constant prices [8]. Direct investment expenditure coefficients matrix and limiting coefficients were constructed for the dynamic optimization model with one or more lags. Leontief inverse matrix was determined, Markov chain was constructed on the base of direct material expenditure coefficients matrix, transposing input-output matrices into transition one. Optimization methods, Solver application, RAS method software (proper elaboration) were utilized.

\section{Own results and discussions}

\subsection{Static input-output model for the Republic of Moldova}

Input-Output table elaboration in the Republic of Moldova has been started since USSR by the State Planning Institute. Our country at that time has occupied leading position at the diverse dimensions input-output table elaboration. After tearing of the USSR, this task was incumbent on the Institute of the Market Problems and to the National Bureau of Statistics. At present, principal elements of the inputoutput tables could be extracted from National Accounts. Regretfully, from the year 2015 this data for input-output table elaborating was ceased.

Researching of the interbranch models based on the input-output tables has been effectuated by the institutes of the Academy of Sciences of Moldova such as: Institute of Mathematics and Computer Science "Vladimir Andrunachievici", National Institute of Economic Research and the Institute of Energetic, which shows a major interest in the interbranch models examination.

Relying on the data in current prices for the 23 branches from the National Accounts of the Republic of Moldova, years 1996-2014, input-output table in constant prices in their classic form was constructed. Namely, for mentioned years, information was selected and processed. This data has formed I-III quadrant of the interbranch balances in constant prices. 
Having input-output tables for year 2014 in the structure of the $n$ (23) examined branches the model of the economic development will be formulated and solved. Four branches: Public administration and defense (L), Associate activities not included in other activities (091), Recreation, culture and sport activities (092) and Other activities and services (093) are not productive branches. Having zero over the line, these branches consume only, so do not affect the matrix of direct material expenditure, thus may be excluded from the interbranch balance. The interbranch static and dynamic models have been studied in [6-11], based on it, much simulation was done. Further static optimization problem based on the inputoutput table for the year 2014 will be formulated.

An input-output table (year 2014) for the 19 productive aggregate industries of the Moldovan economy is principalelement when static optimization problem is formulated. Our country being in profound scarcity of the proper sources of energy, is imposed to import it in sufficient large proportions for covering own necessities. As a result, both growing of the world prices of energy resources and internal tariffs growing, contribute to the domestic prices of the energy resources changing. This in its turn affects both production sector in total and households dramatically influencing country energy security and wellbeing of the population, being on the limit of poverty. So, the problem of energy tariffs growth studying, in this context has major importance.

Interbranch balances can be very useful in the structure of 19 productive aggregate industries, from which aggregate industry of Electric energy, gase and water being one on the whole based on import. So, we will research the influence of the energy tariffs growing on the economy as a whole and on the population in special using interbranch static optimization models.

Suppose that energy tariffs grow 1.5 times, then components of technology vector will grow at the same rate. In such circumstances, what will be the impact on Gross Domestic Product? Knowing output volume $x$ in the one specified year, having modified electric industry technology vector (E), mentioned problem will be formulated as a problem of final consumption optimization. It can be mentioned that both elements of the input-output tables, output vector, and final consumption vector are measured in constant prices. So, the following static optimization problem needs to be solved: maximize final consumption when energy resources tariffs are increasing (changing vector-column (E) and fixing output volume vector value). Then formalized model is written as:

$$
\max \sum_{i=1}^{19} y_{i}
$$

subject to the following restriction $(I-A)^{-1} Y=X$,

here $X$ is the output vector volume which is known and $Y$ is the final demand vector, that must be maximized or

$$
\max \sum_{i=1}^{19} x_{i}
$$

subject to the following restriction $X-A X=Y$.

Let's examined matrices of the direct material expenditure $A$ in money values. Elements of these matrices are less than one and its sum along the column and line is strictly smaller than one. Matrix $A$, constructed from statistical data [8] for year 2014 satisfied partly the earlier exposed particularities, namely, the sum along the column is less than one, but the sum along the line for some industries for example (Processing industry) is greater than one. In such circumstances inverse matrix existence do not done. Such phenomena implies problem in satisfying restriction (6). This imposed to done simulations based on the problem (7), changing prices following restriction (8).

\subsection{Simulation`s calculations}

Expenditure changes in respect to price modification

\begin{tabular}{|l|c|c|c|c|c|c|c|c|c|c|}
\hline Expenditure E & 28500717 & 2843392 & 31307171 & 30698998 & 30359116 & 29846954 & 29211061 & 28548610 & 29411015 & 28962435 \\
\hline Resources $X$ & 221303904 & 4298115 & 1836452 & 192390282 & 201135294 & 218661243 & 221303904 & 227370333 & 236115346 & 244860358 \\
\hline Prices & 1 & 1,05 & 1,1 & 1,15 & 1,2 & 1,25 & 1,3 & 1,4 & 1,45 & 1,5 \\
\hline Iterations & 1 & 2 & 3 & 4 & 5 & 6 & 7 & 8 & 9 & 10 \\
\hline
\end{tabular}

Source: Author's calculations. 
Simulation calculations effectuated in concordance with price modifications demonstrate that price growing can be only applied till 1,3 limit, after that some components of the Gross Domestic Product become negative, challenging economy collapse.

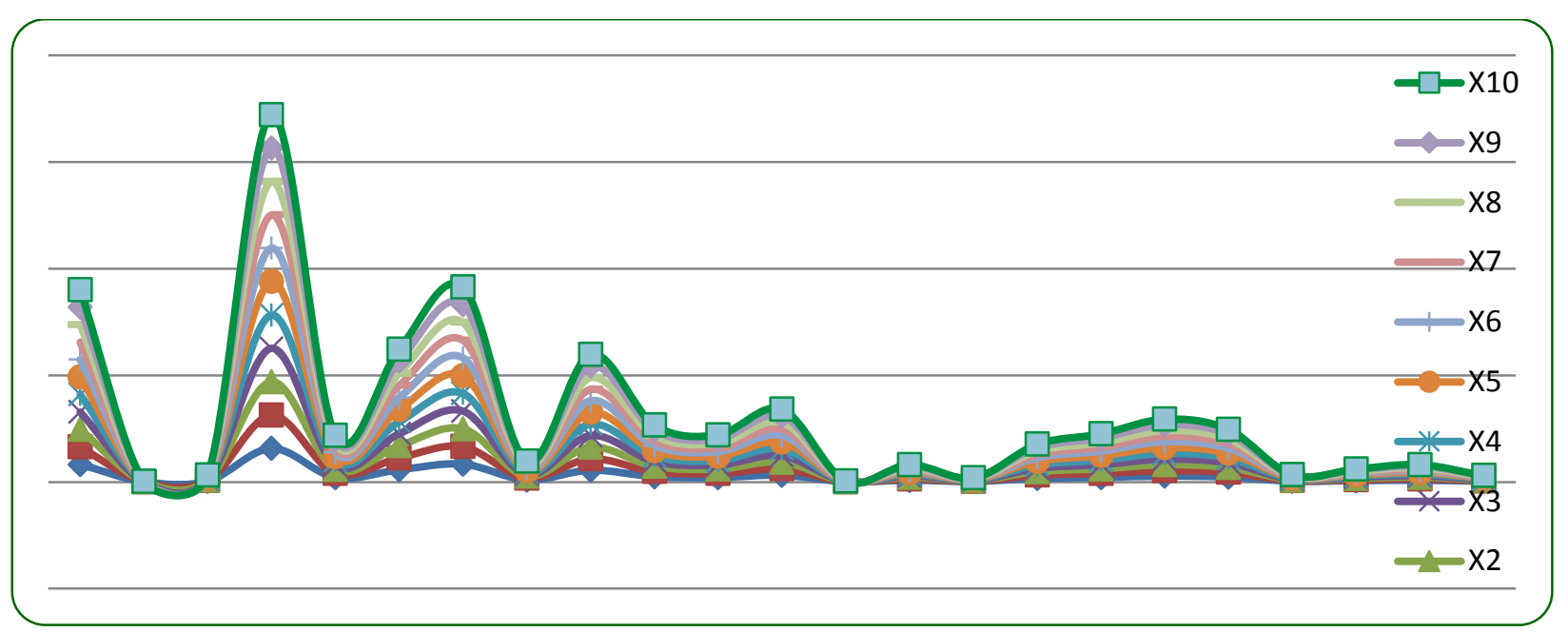

Figure 1. Resource modification relative to price changing Source: Author's calculations.

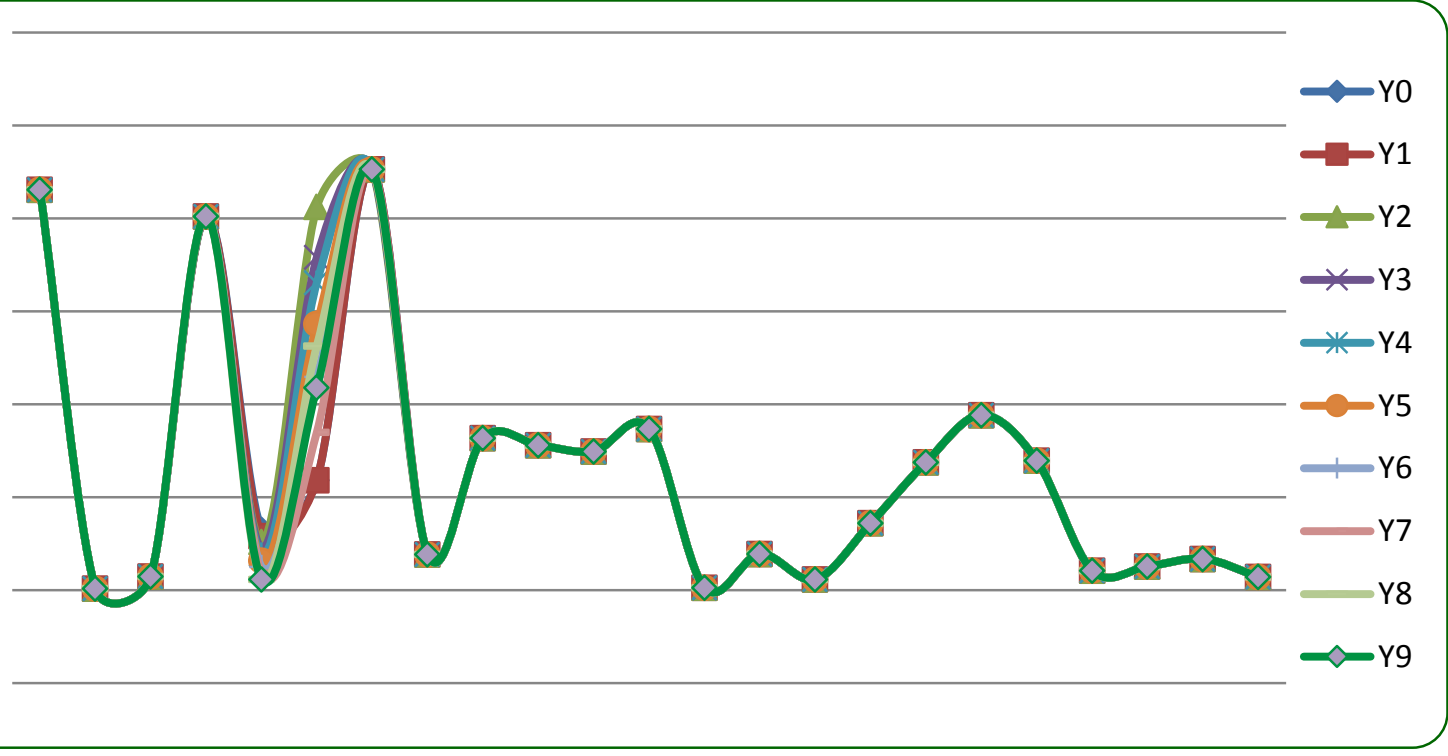

Figure 2. Modifications in Gross Domestic Product relative to price changing Source: Author's calculations.

\subsection{Conclusions}

It must be mentioned that through this study, the utility of the proposed tool, based on the input-output tables constructed on the money flows in constant prices [8] for years 1996-2014, was demonstrated. Two static optimization models (1)-(2) based on the data from year 2014 have been solved. The first model, given satisfied interbranch balance restrictions, starts with known volume of production in order to maximize final consumption. The second model deals with production volume maximizing, given known final consumption and interbranch restrictions satisfied. Calculations results have demonstrated that upper limits of the price increasing is equal to $30 \%$, after that some components of the final demand become negative, which ascertained that final demand can not be satisfied. Using interbranch balance for 2014 year, it could be possible to demonstrate that energy resources tariffs growth, have negative impact on the Gross Domestic Product, which influences both economy as a hole and population especially. Such analysis can be effectuated for every industry from 
those 19 examined in accordance with proposed objective. It is very unfortunate to know that beginning from year 2015 interbranch tables elaboration in the classical manner was ceased.

Another examined aspect is referred to the input-output tables unbalance namely that sum over line may be greater than one, as result it is not equal to the column sum, which is less than one. This industries utilized resources exceeding more production volume, using in plenty import resources (especially energy resources) surpassing domestic production. Input-output table balancing problem is possible to be solved by using RAS method. Next, RAS method description and application follows.

\subsection{Input-output matrices balancing}

Table 2

Sum of the direct material expenditure matrices coefficients along the columns and lines

\begin{tabular}{|l|c|c|c|c|c|}
\hline \multicolumn{1}{|c|}{ Aggregate branches } & $\sum_{i} a_{i j}$ & $\sum_{j} a_{i j}$ & $x_{i}$ & $x_{i}-\sum_{i} a_{i j} x_{i}$ & $x_{i}-\sum_{j} a_{i j} x_{j}$ \\
\hline $\begin{array}{l}\text { A Agriculture, hunting economy } \\
\text { and forestry }\end{array}$ & 0.65 & 0.47 & 8194443 & 4307985 & 3617782 \\
\hline B Fishing & 0.01 & 0.45 & 27364.6 & 14925 & 26046 \\
\hline C Mining & 0.44 & 0.52 & 303098.6 & 145482 & 1449980 \\
\hline D Processing industry & $\mathbf{5 . 9 4}$ & $\mathbf{0 . 7 4}$ & 15657828 & 4022168 & 20667046 \\
\hline $\begin{array}{l}\text { E Water distribution; waste } \\
\text { administration }\end{array}$ & 0.72 & 0.67 & 1985815 & 650721 & 1498246 \\
\hline F Construction & 0.39 & 0.79 & 5660514 & 1185158 & 822897 \\
\hline G Wholesale and retail trading & 0.07 & 0.46 & 8310259 & 4528646 & 237941 \\
\hline H Hotels and restaurants & 0.16 & 0.57 & 892875.4 & 384848 & 287496 \\
\hline 160-63 Transport and storing & 0.63 & 0.70 & 5439666 & 1636009 & 2207758 \\
\hline 164 Communications & 0.45 & 0.36 & 2427941 & 1560084 & 862180 \\
\hline J Financial activity & 0.35 & 0.26 & 2011364 & 1492015 & 934737 \\
\hline K70 Estate transactions & 0.65 & 0.44 & 3103366 & 1735042 & 1474654 \\
\hline K71 Cars and equipments rent & 0.02 & 0.39 & 38119.96 & 23372 & 16664 \\
\hline K72 Computers and adjoint activity & 0.13 & 0.48 & 743423.5 & 387512 & 141666 \\
\hline K73 Investigations - elaborations & 0.05 & 0.34 & 173374.3 & 113617 & 66855 \\
\hline K74 Other commercial activities & 0.31 & 0.55 & 1611441 & 719303 & 862941 \\
\hline L Public administration and defense & 0 & 0.33 & 2049550 & 1376683 & 73720 \\
\hline M Education & 0.03 & 0.29 & 2680886 & 1884680 & 47213 \\
\hline N Health and social assistance & 0.02 & 0.38 & 2241138 & 1391747 & 121516 \\
\hline O90 Recovering and waste removing & 0.08 & 0.32 & 306535.1 & 208836 & 0 \\
\hline $\begin{array}{l}\text { O91 Activities not included in other } \\
\text { categories }\end{array}$ & 0 & 0.55 & 558130.2 & 253929 & 0 \\
\hline $\begin{array}{l}\text { O92 Recreation, cultural and sport } \\
\text { activities }\end{array}$ & 0 & 0.55 & 744108.9 & 336151 & 0 \\
\hline O93 Other activities and services & 0 & 0.49 & 277459.9 & 141804 & 3617782 \\
\hline
\end{tabular}

Source: Author's calculations.

Table 2 offers calculations of the sum direct material expenditure matrices coefficients along the columns and lines, effectuated in accordance with model data. Showed noticed from this table that column sum over the column is less than one for all examined branches but sum over line of the Processing industry exceeds much more one unit, in such a manner encroach upon productivity property of the direct material expenditure coefficients matrices. Second observation certified that double accounting rule don't have to stand. To surpass this phenomena one will e appeal to the RAS [13] method, well known and wide utilized automation tool for balancing input-output matrices. Main objective of the RAS method consists in column and line balancing of the input-output matrices, in other words balancing demand and use through modification and revising of initial input-output table. Main equation which is cyclic dependent on the existing discrepancy can be written as: 
$X_{C}^{\text {new }}\left(t_{n}\right) \cdot X_{C}^{\text {new }}\left(t_{n-1}\right) \cdot \ldots \cdot X_{C}^{\text {new }}\left(t_{1}\right) \cdot A \cdot X_{R}^{\text {new }}\left(t_{1}\right) \cdot \ldots \cdot X_{R}^{\text {new }}\left(t_{n-1}\right) \cdot X_{R}^{\text {new }}\left(t_{n}\right)=A^{\text {new }}$.

Here

$X_{C}^{\text {new }}\left(t_{1}\right)$ is the new volume production vector over column at the time $t_{1}$,

$A$ is the direct material expenditure matrix,

$X_{R}^{\text {new }}\left(t_{1}\right)$ is the new volume production vector over line at the time $t_{1}$.

These equations have been easy solved with special soft or by utilizing Excel applications.

Being known precise sums over columns and lines in practice this method is reduced to revising existent totals over columns and lines so as it coincides with that precise. The RAS adjustments can be seen as one iterative process in which columns and lines (lines and columns) have been modified successively in order to obtain correct balanced totals over columns and lines so as differences among two consecutive lines be equal to zero.

At the first step $\left(t_{1}\right)$ (first iteration), matrix $A$ will be replaced by the line sum in concordance with the formula: $A_{R}^{\text {new }}\left(t_{1}\right)=\cdot X_{R}^{\text {new }}\left(t_{1}\right) \cdot A$

Procedure is applied to all matrix $A$ lines. At the second step (first iteration) all column sums are recalculated in concordance with formula: $A_{C}^{\text {new }}\left(t_{1}\right)=\cdot X_{C}^{\text {new }}\left(t_{1}\right) \cdot A$.

First iteration is finalized with the matrix $A$ recalculated over columns and lines as follow $A^{\text {new }}\left(t_{1}\right)=X_{C}^{\text {new }}\left(t_{1}\right) \cdot A \cdot X_{R}^{\text {new }}\left(t_{1}\right)$.

Input-output table initial data before applying RAS procedure mil lei

Table 3

\begin{tabular}{|c|c|c|c|c|c|c|c|c|c|c|c|}
\hline $\begin{array}{l}\text { Data in mil lei, } \\
\text { constant prices }\end{array}$ & $\mathbf{A}$ & B & C & D & $\mathbf{E}$ & $\mathbf{F}$ & G & $\mathbf{H}$ & $160-63$ & 164 & $\mathbf{J}$ \\
\hline $\begin{array}{l}\text { A Agriculture, hunting economy } \\
\text { and forestry }\end{array}$ & 1452154 & 4436 & 0 & 2000419 & 0 & 28031 & 29847 & 81591 & 0 & 0 & 0 \\
\hline B Fishing & 0 & 1 & 0 & 20161 & 0 & 0 & 1890 & 1219 & 0 & 0 & 0 \\
\hline C Mining & 57053 & 33 & 59 & 393858 & 322219 & 421803 & 53898 & 14088 & 17250 & 3304 & 1193 \\
\hline D Processing industry & 2225370 & 6147 & 109014 & 7755851 & 542075 & 3567832 & 1315381 & 251983 & 2141284 & 325315 & 101408 \\
\hline E Electric energy, gase, water & 41203 & 653 & 9484 & 320939 & 242408 & 26013 & 197846 & 47139 & 94006 & 146554 & 15007 \\
\hline F Construction & 0 & 0 & 4076 & 194858 & 33087 & 103635 & 51275 & 15649 & 82651 & 53258 & 51162 \\
\hline G Wholesale and retail trading & 0 & 0 & 0 & 66789 & 11179 & 6319 & 38772 & 2985 & 48556 & 8163 & 11803 \\
\hline H Hotels and restaurants & 1564 & 38 & 521 & 24229 & 2951 & 35096 & 82510 & 762 & 71752 & 4154 & 2861 \\
\hline 160-63Transport and storing & 48850 & 166 & 30891 & 322883 & 34823 & 63718 & 564646 & 4542 & 889936 & 78445 & 16272 \\
\hline 164 Communications & 12232 & 165 & 511 & 88005 & 36106 & 39813 & 113264 & 22217 & 114752 & 153710 & 33824 \\
\hline J Financial activities & 7177 & 92 & 701 & 71932 & 56425 & 27614 & 345550 & 8845 & 93080 & 13043 & 221442 \\
\hline K70 Estate transactions & 13681 & 258 & 1657 & 167510 & 12464 & 128751 & 617018 & 23065 & 169002 & 19204 & 16641 \\
\hline K71 Cars and equipments rent & 0 & 0 & 0 & 312 & 0 & 0 & 0 & 218 & 1089 & 65 & 41 \\
\hline $\begin{array}{l}\text { K72 Computers and adjoint } \\
\text { activity }\end{array}$ & 4749 & 35 & 0 & 10232 & 5757 & 5489 & 0 & 4026 & 6928 & 8372 & 6614 \\
\hline K73 Investigations - elaborations & 7879 & 0 & 0 & 30759 & 1819 & 636 & 0 & 520 & 2072 & 1408 & 698 \\
\hline K74 Other commercial activities & 13756 & 398 & 545 & 132954 & 24649 & 6646 & 332874 & 16425 & 57195 & 40887 & 33512 \\
\hline M Education & 0 & 6 & 129 & 8726 & 2396 & 1178 & 10600 & 1687 & 7788 & 8630 & 2332 \\
\hline $\mathrm{N}$ Health and social assistance & 793 & 14 & 0 & 0 & 0 & 0 & 1643 & 0 & 0 & 0 & 0 \\
\hline $\begin{array}{l}\text { 090 Recovering and waste } \\
\text { removing }\end{array}$ & 0 & 0 & 28 & 25243 & 6735 & 12782 & 24595 & 11066 & 6316 & 3346 & 4540 \\
\hline $\begin{array}{l}\text { A Agriculture, hunting economy } \\
\text { and forestry }\end{array}$ & 3886462 & 12440 & 157617 & 11635660 & 1335093 & 4475356 & 3781612 & 508028 & 3803658 & 867859 & 519349 \\
\hline B Fishing & 3886462 & 12440 & 157617 & 11635660 & 1335093 & 4475356 & 3781612 & 508028 & 3803658 & 867859 & 519349 \\
\hline C Mining & 0 & 0 & 0 & 0 & 0 & 0 & 0 & 0 & 0 & 0 & 0 \\
\hline
\end{tabular}




\begin{tabular}{|c|c|c|c|c|c|c|c|c|c|c|}
\hline $\begin{array}{l}\text { Data in mil lei, } \\
\text { constant prices }\end{array}$ & K70 & K71 & K72 & K73 & K74 & M & $\mathbf{N}$ & 090 & Line`s sum & Correct sum \\
\hline A & 0 & 0 & 0 & 3762 & 0 & 7245 & 10298 & 0 & 3617782 & 3886462 \\
\hline B & 0 & 0 & 0 & 0 & 0 & 626 & 2149 & 0 & 26046 & 12440 \\
\hline $\mathrm{C}$ & 52932 & 50 & 1994 & 962 & 2208 & 57387 & 46117 & 3571 & 1449980 & 157617 \\
\hline D & 666487 & 5071 & 153753 & 20905 & 494036 & 399234 & 538800 & 47098 & 20667046 & 11635660 \\
\hline E & 171257 & 733 & 6897 & 3456 & 10361 & 105962 & 53869 & 4458 & 1498246 & 1335093 \\
\hline $\mathrm{F}$ & 72239 & 345 & 795 & 11799 & 27980 & 70995 & 45663 & 3428 & 822897 & 4475356 \\
\hline G & 14161 & 0 & 329 & 531 & 22631 & 1603 & 3974 & 147 & 237941 & 3781612 \\
\hline $\mathrm{H}$ & 7707 & 44 & 3939 & 1084 & 20080 & 15227 & 4929 & 8050 & 287496 & 508028 \\
\hline $160-63$ & 25519 & 390 & 18008 & 3826 & 71576 & 15163 & 15754 & 2348 & 2207758 & 3803658 \\
\hline 164 & 74832 & 157 & 57778 & 1416 & 79611 & 13721 & 13184 & 6883 & 862180 & 867859 \\
\hline $\mathrm{J}$ & 28956 & 535 & 17736 & 893 & 12878 & 6272 & 13377 & 8188 & 934737 & 519349 \\
\hline K70 & 163450 & 6353 & 29377 & 1916 & 69923 & 23517 & 7954 & 2914 & 1474654 & 1368324 \\
\hline K71 & 127 & 0 & 0 & 62 & 77 & 4966 & 9600 & 108 & 16664 & 14748 \\
\hline K72 & 10639 & 299 & 51233 & 1032 & 4290 & 7479 & 12509 & 1984 & 141666 & 355942 \\
\hline K73 & 0 & 0 & 3078 & 5777 & 2730 & 4189 & 5291 & 0 & 66855 & 59757 \\
\hline K74 & 70470 & 483 & 8518 & 1799 & 60164 & 49925 & 8903 & 2839 & 862941 & 892138 \\
\hline M & 1290 & 12 & 1240 & 107 & 9560 & 8896 & 7825 & 1317 & 73720 & 796206 \\
\hline $\mathrm{N}$ Health & 0 & 0 & 0 & 0 & 0 & 0 & 44763 & 0 & 47213 & 849392 \\
\hline 090 & 8259 & 273 & 1267 & 429 & 4034 & 3799 & 4434 & 4368 & 121516 & 97699 \\
\hline Coloan`s sum & 1368324 & 14748 & 355942 & 59757 & 892138 & 796206 & 849392 & 97699 & & \\
\hline Correct sum & 1368324 & 14748 & 355942 & 59757 & 892138 & 796206 & 849392 & 97699 & & \\
\hline Balansing & 0 & 0 & 0 & 0 & 0 & 0 & 0 & 0 & & \\
\hline
\end{tabular}

\section{Source: Author`s calculations.}

Then equality of the new sums over columns and lines is verified. If the equality of the new sums over columns or lines doesn't exist, then matrix $A^{\text {new }}\left(t_{1}\right)$ is copied and replaced instead of the matrix $A$. Iterations are repeated till both column sums and line sums coincide with that correct one, and namely with differences along the sum between last two iterations being equal to zero.

In conclusion, for RAS procedure application it is necessary to indicate data for direct material expenditure coefficients matrix $A$ (with $n$ lines and $n$ columns) and correct sums over respective columns and lines. Then the balancing procedure realized in Excel application can be applied.

Table 4

Input-output table initial data after applying RAS procedure (mil lei)

\begin{tabular}{|l|c|c|c|c|c|c|c|c|c|c|c|}
\hline $\begin{array}{l}\text { Iteration 63. Line } \\
\text { transformations }\end{array}$ & $\mathbf{A}$ & $\mathbf{B}$ & $\mathbf{C}$ & $\mathbf{D}$ & $\mathbf{E}$ & $\mathbf{F}$ & $\mathbf{G}$ & $\mathbf{H}$ & $\mathbf{1 6 0 - 6 3}$ & $\mathbf{1 6 4}$ & J \\
\hline A & 1785404 & 4510 & 0 & 1972238 & 0 & 33450 & 18718 & 64735 & 0 & 0 & 0 \\
\hline B & 0 & 0 & 0 & 10872 & 0 & 0 & 648 & 529 & 0 & 0 & 0 \\
\hline C & 7926 & 4 & 6 & 43874 & 33193 & 56872 & 3819 & 1263 & 1196 & 195 & 61 \\
\hline D & 1680428 & 3838 & 54992 & 4696367 & 303547 & 2614945 & 506628 & 122790 & 807227 & 104328 & 28268 \\
\hline E & 59883 & 785 & 9208 & 374035 & 261259 & 36695 & 146663 & 44211 & 68208 & 90459 & 8051 \\
\hline F & 0 & 0 & 24377 & 1398725 & 219636 & 900423 & 234114 & 90401 & 369360 & 202468 & 169062 \\
\hline G & 0 & 0 & 0 & 1441519 & 223125 & 165072 & 532281 & 51853 & 652450 & 93314 & 117271 \\
\hline H & 4785 & 96 & 1064 & 59454 & 6697 & 104238 & 128782 & 1505 & 109614 & 5398 & 3232 \\
\hline $160-63$ & 147949 & 416 & 62501 & 784174 & 78210 & 187309 & 872266 & 8878 & 1345598 & 100901 & 18192 \\
\hline 164 & 22464 & 251 & 627 & 129601 & 49171 & 70965 & 106096 & 26330 & 105208 & 119885 & 22931 \\
\hline J & 7609 & 80 & 496 & 61149 & 44358 & 28414 & 186846 & 6051 & 49262 & 5873 & 86660 \\
\hline
\end{tabular}




\begin{tabular}{|l|c|c|c|c|c|c|c|c|c|c|c|}
\hline $\begin{array}{l}\text { Iteration 63. Line } \\
\text { transformations }\end{array}$ & $\mathbf{A}$ & $\mathbf{B}$ & $\mathbf{C}$ & $\mathbf{D}$ & $\mathbf{E}$ & $\mathbf{F}$ & $\mathbf{G}$ & $\mathbf{H}$ & $\mathbf{1 6 0 - 6 3}$ & $\mathbf{1 6 4}$ & J \\
\hline K70 & 21687 & 338 & 1755 & 212928 & 14652 & 198093 & 498878 & 23594 & 133744 & 12928 & 9738 \\
\hline K71 & 0 & 0 & 0 & 771 & 0 & 0 & 0 & 433 & 1675 & 85 & 46 \\
\hline K72 & 22177 & 134 & 0 & 38315 & 19935 & 24879 & 0 & 12132 & 16151 & 16603 & 11402 \\
\hline K73 & 10685 & 0 & 0 & 33451 & 1829 & 837 & 0 & 455 & 1403 & 811 & 350 \\
\hline K74 & 25595 & 612 & 677 & 198367 & 34010 & 12002 & 315903 & 19722 & 53127 & 32309 & 23017 \\
\hline M & 0 & 102 & 1891 & 153604 & 39001 & 25095 & 118695 & 23898 & 85350 & 80461 & 18897 \\
\hline N & 89869 & 1275 & 0 & 0 & 0 & 0 & 95028 & 0 & 0 & 0 & 0 \\
\hline O90 & 0 & 0 & 24 & 26217 & 6469 & 16069 & 16248 & 9250 & 4084 & 1841 & 2171 \\
\hline Coloan`s sum & 3886462 & 12440 & 157617 & 11635660 & 1335093 & 4475356 & 3781612 & 508028 & 3803658 & 867859 & 519349 \\
\hline Correct sum & 3886462 & 12440 & 157617 & 11635660 & 1335093 & 4475356 & 3781612 & 508028 & 3803658 & 867859 & 519349 \\
\hline Balansing & 0 & 0 & 0 & 0 & 0 & 0 & 0 & 0 & 0 & 0 & 0 \\
\hline
\end{tabular}

\begin{tabular}{|c|c|c|c|c|c|c|c|c|c|c|}
\hline $\begin{array}{l}\text { Iteration 63. Line } \\
\text { transformations }\end{array}$ & K70 & K71 & K72 & K73 & K74 & M & $\mathbf{N}$ & 090 & Line`s sum & $\begin{array}{c}\text { Correct } \\
\text { sum }\end{array}$ \\
\hline A & 0 & 0 & 0 & 1485 & 0 & 4267 & 1655 & 0 & 3886462 & 3886462 \\
\hline B & 0 & 0 & 0 & 0 & 0 & 202 & 189 & 0 & 12440 & 12440 \\
\hline $\mathrm{C}$ & 3968 & 4 & 147 & 43 & 127 & 3819 & 837 & 263 & 157617 & 157617 \\
\hline $\mathrm{D}$ & 271589 & 2439 & 61812 & 5070 & 154948 & 144417 & 53176 & 18852 & 11635660 & 11635660 \\
\hline $\mathrm{E}$ & 134315 & 679 & 5337 & 1613 & 6254 & 73773 & 10233 & 3434 & 1335093 & 1335093 \\
\hline $\mathrm{F}$ & 348957 & 1969 & 3791 & 33920 & 104029 & 304437 & 53423 & 16264 & 4475356 & 4475356 \\
\hline G & 205682 & 0 & 4712 & 4590 & 252999 & 20668 & 13981 & 2097 & 3781612 & 3781612 \\
\hline $\mathrm{H}$ & 12726 & 86 & 6417 & 1065 & 25521 & 22321 & 1971 & 13057 & 508028 & 508028 \\
\hline $160-63$ & 41708 & 753 & 29037 & 3722 & 90039 & 21999 & 6236 & 3770 & 3803658 & 3803658 \\
\hline 164 & 74160 & 184 & 56491 & 835 & 60725 & 12071 & 3165 & 6700 & 867859 & 867859 \\
\hline $\mathrm{J}$ & 16565 & 361 & 10010 & 304 & 5670 & 3185 & 1853 & 4601 & 519349 & 519349 \\
\hline K70 & 139818 & 6413 & 24792 & 975 & 46037 & 17858 & 1648 & 2448 & 1368324 & 1368324 \\
\hline K71 & 211 & 0 & 0 & 61 & 98 & 7327 & 3865 & 176 & 14748 & 14748 \\
\hline K72 & 26810 & 889 & 127371 & 1548 & 8320 & 16731 & 7634 & 4910 & 355942 & 355942 \\
\hline K73 & 0 & 0 & 2223 & 2516 & 1538 & 2721 & 938 & 0 & 59757 & 59757 \\
\hline K74 & 70756 & 573 & 8437 & 1075 & 46494 & 44498 & 2165 & 2800 & 892138 & 892138 \\
\hline $\mathrm{M}$ & 15287 & 174 & 14491 & 757 & 87169 & 93553 & 22452 & 15329 & 796206 & 796206 \\
\hline $\mathrm{N}$ Health & 0 & 0 & 0 & 0 & 0 & 0 & 663220 & 0 & 849392 & 849392 \\
\hline 090 & 5773 & 225 & 874 & 179 & 2170 & 2357 & 751 & 2999 & 97699 & 97699 \\
\hline Coloan`s sum & 1368324 & 14748 & 355942 & 59757 & 892138 & 796206 & 849392 & 97699 & & \\
\hline Correct sum & 1368324 & 14748 & 355942 & 59757 & 892138 & 796206 & 849392 & 97699 & & \\
\hline Balansing & 0 & 0 & 0 & 0 & 0 & 0 & 0 & 0 & & \\
\hline
\end{tabular}

Source: Author`s calculations.

\section{Dynamic input-output model for the Republic of Moldova}

\subsection{Model structure}

Optimization models present special interest in its application for economic problems solving. Peculiarity of the optimization models consists in the possibility to elaborate methods for efficient using of the limited resources for maintaining sustainable economic development. Further, dynamic optimization model for Republic of Moldova will be presented. Input-output table`s statistic data for Republic of Moldova have been collected from National Accounts (years 2000-2014) in the structure of 19 industrial branches) in concordance with European Union Standards. Objective function deals with maximizing the Gross Domestic Product restricted by limited energy consumption for the period of [1,T]: 


$$
\max f\left(x_{t}\right)=\sum_{t=1}^{T} e^{\prime}\left(x_{t}-A_{t} x_{t}\right)
$$

Here, $x_{t}$ is the vector of the production volume, $A_{t}$ is the matrix of the direct material expenditures and $e$ is the unity vector.

Objective maximization function is followed to meet following restrictions:

$$
\begin{aligned}
& C_{t} \geq c_{t}^{\prime} x_{t} \\
& x_{t}=A_{t} x_{t}+B_{t}\left(x_{t+1}-x_{t}\right)+y_{1 t}+y_{2 t}, \\
& \left(s_{t}+s_{f t}\right) e^{\prime}\left(x_{t}-A_{t} x_{t}\right) \geq e^{\prime} B_{t}\left(x_{t+1}-x_{t}\right), \\
& \left(1-s_{t}\right) e^{\prime}\left(x_{t}-A_{t} x_{t}\right) \geq e^{\prime} y_{1 t}, \\
& s_{f t} e^{\prime}\left(x_{t}-A_{t} x_{t}\right) \geq-e^{\prime} y_{2 t}, \\
& q_{1} x_{t-1} \geq x_{t} \geq q_{2} x_{t-1}, \\
& x_{t}, y_{1 t} \geq 0 .
\end{aligned}
$$

In previous relationships $c_{t}$ is the vector of energy consumption needed for production of the one unit of output in industries examined at the moment $t ; B$ is the matrix of the investment coefficients; $y_{1 t}$ is the final consumption vector; $y_{2 t}$ is the vector of net export; $s_{t}$ is the rate of internal savings, equal to (0.62), $s_{f t}$ is the weight of the foreign capital in GDP, equal to $0.67 ; q_{1}$ is the fast growth limited coefficient, equal to $1.127 ; q_{2}$ is the coefficient of economic recession limit, equal to 0.873 . The investment coefficients of the matrix $B_{t}$ were calculated according to the following formula:

$$
b_{i j t}=\frac{\Delta s_{i t} a_{i j t}}{\Delta x_{j(t+1)} \sum_{j=1}^{n} a_{i j t}} .
$$

Optimization model formulated earlier, endowed with determined $b_{i j t}$ coefficients, have been solved using Solver application and the following conclusions were done.

\subsection{Calculating model parameters and forecasting}

Table 6

Macroeconomic indicators values for st and stf

\begin{tabular}{|l|c|c|c|c|c|c|}
\hline Indices & Year 2010 & Year 2011 & Year 2012 & Year 2013 & Year 2014 & Mean \\
\hline st & -0.6714 & -0.6961 & -0.6818 & -0.4089 & -0.6243 & -0.6165 \\
\hline sft & 0.6714 & 0.6961 & 0.6818 & 0.6478 & 0.6243 & 0.6643 \\
\hline
\end{tabular}

Source: Author's calculations.

Table 7

Energy's Industry intermediate consumption

\begin{tabular}{|l|l|l|l|l|l|r|}
\hline Years & Year 2010 & Year 2011 & Year 2012 & Year 2013 & Year 2014 & Max $\boldsymbol{C}_{\boldsymbol{t}}$ \\
\hline $\boldsymbol{C}_{\boldsymbol{t}}$ & 3664845.609 & 4152344 & 4421277 & 4867877 & 5373075 & 5373075 \\
\hline
\end{tabular}

Source: Author`s calculations.

Table 8

GDP forecasted values in (mil lei)

\begin{tabular}{|l|l|c|c|c|}
\hline $\begin{array}{l}\text { Objective } \\
\text { function }\end{array}$ & Year 2015 & Year 2016 & Year 2017 & Year 2018 \\
\hline GDP & 104512319.9 & 110708443.8 & 117496102.2 & 127693108.6 \\
\hline
\end{tabular}

Source: Author`s calculations.

\subsection{Conclusions}


Economic development scenario restricted by energy saving polices have been elaborated dealing with small changes, in the limits of existing possibilities. So, following results presented in Table 9, small diminishing of the energy industry volume in the Gross Domestic Product structure and increasing weight in the services industries were confirmed. In conclusion, to reach energy saving it is necessary to develop such services industries which consume a small volume of energy resources: only human resources and energy preserving technologies.

Table 9

Forecasting results (year2018)

\begin{tabular}{|c|c|c|c|c|}
\hline Aggregate branches & Year 2015 & Year 2016 & Year 2017 & Year 2018 \\
\hline A Agriculture, forestry and fishing & 12,9178 & 14,0059 & 15,9075 & 15,9075 \\
\hline B Mining & 0,4762 & 0,5163 & 0,5562 & 0,5864 \\
\hline C Processing industry & 24,6010 & 20,6616 & 17,2410 & 14,0811 \\
\hline D Production and supplying of electric energy & 3,1200 & 2,6404 & 2,1866 & 1,7858 \\
\hline$E$ Water distribution; waste administration & 1,3585 & 1,4730 & 1,5867 & 1,6729 \\
\hline$F \quad$ Construction & 8,8936 & 9,6427 & 10,3874 & 10,9519 \\
\hline$G \quad$ Wholesale and retail trading & 12,7075 & 13,7779 & 14,8419 & 15,6485 \\
\hline$H \quad$ Transport and storing & 8,5466 & 9,6427 & 9,9821 & 10,5246 \\
\hline 1 Accommodation and public feed & 1,4029 & 1,5210 & 1,6385 & 1,7275 \\
\hline J Information and communications & 3,8597 & 2,5360 & 0,7761 & 0,8183 \\
\hline$K$ Financial activity and insurance & 2,4480 & 2,6541 & 2,8591 & 3,0145 \\
\hline L Estate transactions & 4,8759 & 5,2866 & 5,6949 & 5,2798 \\
\hline M Professional, research and technical activities & 0,2724 & 0,2953 & 0,3182 & 0,3354 \\
\hline$N$ Professional services offer and support activities & 1,9612 & 2,1264 & 2,2906 & 2,4151 \\
\hline$O$ Public administration and defense & 3,2202 & 3,4914 & 3,7611 & 3,9655 \\
\hline P Education & 4,2121 & 4,5669 & 4,9196 & 5,1870 \\
\hline$Q$ Health and social assistance & 3,5212 & 3,8178 & 4,1126 & 4,3361 \\
\hline$R$ Art, research and pleasure activity & 1,1691 & 1,2676 & 1,3655 & 1,4397 \\
\hline S Other activities and services & 0,4359 & 0,4727 & 0,3944 & 0,3221 \\
\hline$N$ Professional services offer and support activities & 1,9612 & 2,1264 & 2,2906 & 2,4151 \\
\hline$M$ Professional, research and technical activities & 0,2724 & 0,2953 & 0,3182 & 0,3354 \\
\hline$O$ Public administration and defense & 3,2202 & 3,4914 & 3,7611 & 3,9655 \\
\hline P Education & 4,2121 & 4,5669 & 4,9196 & 5,1870 \\
\hline$Q$ Health and social assistance & 3,5212 & 3,8178 & 4,1126 & 4,3361 \\
\hline$R$ Art, research and pleasure activity & 1,1691 & 1,2676 & 1,3655 & 1,4397 \\
\hline$S$ Other activities and services & 0,4359 & 0,4727 & 0,3944 & 0,3221 \\
\hline
\end{tabular}

Source: Author`s calculations.

Table 10

Direct investment expenditure coefficients matrix

\begin{tabular}{|l|c|c|c|c|c|c|c|c|c|}
\hline \multicolumn{1}{|c}{ Investment matrix Bt } & A & B & C & D & E & F & G & H & I \\
\hline A Agriculture, hunting economy and forestry & 0,00015 & 0 & $2 \mathrm{E}-05$ & 0 & 0 & $2 \mathrm{E}-06$ & $9,2 \mathrm{E}-07$ & 0 & 0,000168 \\
\hline B Mining & $5,4 \mathrm{E}-10$ & $2 \mathrm{E}-09$ & $3 \mathrm{E}-10$ & $2,56 \mathrm{E}-08$ & $7,8 \mathrm{E}-09$ & $2,8 \mathrm{E}-09$ & $1,5 \mathrm{E}-10$ & $7 \mathrm{E}-11$ & $2,69 \mathrm{E}-09$ \\
\hline C IProcessing industry & $5,4 \mathrm{E}-05$ & 0,008 & $2 \mathrm{E}-05$ & 0,000109 & 0,00044 & $6 \mathrm{E}-05$ & $9,2 \mathrm{E}-06$ & $2 \mathrm{E}-05$ & 0,000122 \\
\hline $\begin{array}{l}\text { D Electric energy, thermic energy, gas, hot } \\
\text { water, and conditional air production and } \\
\text { supplying }\end{array}$ & $1,3 \mathrm{E}-06$ & $8 \mathrm{E}-04$ & $9 \mathrm{E}-07$ & $6,22 \mathrm{E}-05$ & $7,6 \mathrm{E}-05$ & $5,6 \mathrm{E}-07$ & $1,8 \mathrm{E}-06$ & $1 \mathrm{E}-06$ & $2,91 \mathrm{E}-05$ \\
\hline $\begin{array}{l}\text { E Water distribution; sanitation, waste } \\
\text { administration, decontamination activities }\end{array}$ & 0 & $1 \mathrm{E}-05$ & $3 \mathrm{E}-07$ & $8,24 \mathrm{E}-06$ & $5,9 \mathrm{E}-05$ & $1,3 \mathrm{E}-06$ & $1 \mathrm{E}-06$ & $4 \mathrm{E}-07$ & $3,25 \mathrm{E}-05$ \\
\hline F Construction & 0 & 0,005 & $7 \mathrm{E}-06$ & 0,000111 & 0,00023 & $2,9 \mathrm{E}-05$ & $6 \mathrm{E}-06$ & $1 \mathrm{E}-05$ & 0,000126 \\
\hline
\end{tabular}




\begin{tabular}{|l|c|c|c|c|c|c|c|c|c|}
\hline \multicolumn{1}{|c|}{ Investment matrix Bt } & A & B & C & D & E & F & G & H & I \\
\hline $\begin{array}{l}\text { G Wholesale and retail trading; îkeeping and } \\
\text { repairing of cars and motocars }\end{array}$ & 0 & 0 & $8 \mathrm{E}-06$ & 0,000121 & $3,3 \mathrm{E}-05$ & $5,7 \mathrm{E}-06$ & $1,4 \mathrm{E}-05$ & $3 \mathrm{E}-05$ & $8,33 \mathrm{E}-05$ \\
\hline H Transport and storing & $5,2 \mathrm{E}-06$ & 0,01 & $3 \mathrm{E}-06$ & $3,09 \mathrm{E}-05$ & $5,8 \mathrm{E}-05$ & $4,7 \mathrm{E}-06$ & $1,7 \mathrm{E}-05$ & $4 \mathrm{E}-05$ & $9,69 \mathrm{E}-06$ \\
\hline $\begin{array}{l}\text { I Accomodation and public nourisment } \\
\text { activities }\end{array}$ & $1,9 \mathrm{E}-08$ & $2 \mathrm{E}-05$ & $2 \mathrm{E}-08$ & $2,87 \mathrm{E}-07$ & $1,2 \mathrm{E}-05$ & $2,9 \mathrm{E}-07$ & $2,8 \mathrm{E}-07$ & $4 \mathrm{E}-07$ & $1,78 \mathrm{E}-07$ \\
\hline J Information and communication & $4 \mathrm{E}-07$ & $3 \mathrm{E}-05$ & $2 \mathrm{E}-07$ & $8,22 \mathrm{E}-06$ & $2,3 \mathrm{E}-05$ & $7,5 \mathrm{E}-07$ & $7,7 \mathrm{E}-07$ & $1 \mathrm{E}-06$ & $1,24 \mathrm{E}-05$ \\
\hline K Financial and asurance activities & $7,2 \mathrm{E}-08$ & $2 \mathrm{E}-05$ & $6 \mathrm{E}-08$ & $4,65 \mathrm{E}-06$ & $7,5 \mathrm{E}-06$ & $1,9 \mathrm{E}-07$ & $9,8 \mathrm{E}-07$ & $4 \mathrm{E}-07$ & $1,75 \mathrm{E}-06$ \\
\hline L Estate tranzactions & $1,5 \mathrm{E}-06$ & $5 \mathrm{E}-04$ & $2 \mathrm{E}-06$ & $1,13 \mathrm{E}-05$ & $6,9 \mathrm{E}-05$ & $9,8 \mathrm{E}-06$ & $2 \mathrm{E}-05$ & $8 \mathrm{E}-06$ & $5,02 \mathrm{E}-05$ \\
\hline $\begin{array}{l}\text { M Professional, scientific and technical } \\
\text { activities }\end{array}$ & $1,6 \mathrm{E}-07$ & 0 & $6 \mathrm{E}-08$ & $3,17 \mathrm{E}-07$ & 0 & $9,3 \mathrm{E}-09$ & 0 & $2 \mathrm{E}-08$ & $2,17 \mathrm{E}-07$ \\
\hline $\begin{array}{l}\text { N Activități de servicii Administration } \\
\text { servivies and support servicies }\end{array}$ & $2,1 \mathrm{E}-07$ & $2 \mathrm{E}-05$ & $2 \mathrm{E}-07$ & $3,05 \mathrm{E}-06$ & $8,5 \mathrm{E}-06$ & $6,9 \mathrm{E}-08$ & $1,4 \mathrm{E}-06$ & $4 \mathrm{E}-07$ & $4,88 \mathrm{E}-06$ \\
\hline P Education & $6,2 \mathrm{E}-09$ & $4 \mathrm{E}-04$ & $8 \mathrm{E}-07$ & $2,22 \mathrm{E}-05$ & 0,00011 & $9,1 \mathrm{E}-07$ & $3,4 \mathrm{E}-06$ & $4 \mathrm{E}-06$ & $3,75 \mathrm{E}-05$ \\
\hline Q Health and social assistance & $6,4 \mathrm{E}-06$ & 0 & 0 & 0 & 0 & 0 & $3,7 \mathrm{E}-06$ & 0 & 0 \\
\hline
\end{tabular}

\begin{tabular}{|c|c|c|c|c|c|c|c|}
\hline Investment matrix Bt & $\mathbf{J}$ & $\mathbf{K}$ & $\mathbf{L}$ & M & $\mathbf{N}$ & $\mathbf{P}$ & $\mathbf{Q}$ \\
\hline $\begin{array}{l}\text { A Agriculture, hunting economy and } \\
\text { forestry }\end{array}$ & 0 & 0 & 0 & $2 \mathrm{E}-05$ & 0 & $3,5 \mathrm{E}-06$ & $1,6 \mathrm{E}-06$ \\
\hline B Mining & $9,09 \mathrm{E}-11$ & $1,3 \mathrm{E}-11$ & $2 \mathrm{E}-09$ & $4 \mathrm{E}-10$ & $1,05 \mathrm{E}-10$ & $2,4 \mathrm{E}-09$ & $5,5 \mathrm{E}-10$ \\
\hline C IProcessing industry & $2,083 \mathrm{E}-05$ & $2,7 \mathrm{E}-06$ & $6 \mathrm{E}-05$ & $2 \mathrm{E}-05$ & $5,96 \mathrm{E}-05$ & $4,2 \mathrm{E}-05$ & $1,6 \mathrm{E}-05$ \\
\hline $\begin{array}{l}\text { D Electric energy, thermic energy, gas, } \\
\text { hot water, and conditional air } \\
\text { production and supplying }\end{array}$ & $8,512 \mathrm{E}-06$ & $5,1 \mathrm{E}-07$ & $2 \mathrm{E}-05$ & $5 \mathrm{E}-06$ & $1,6 \mathrm{E}-06$ & $1,4 \mathrm{E}-05$ & $2,1 \mathrm{E}-06$ \\
\hline $\begin{array}{l}\text { E Water distribution; sanitation, waste } \\
\text { administration, decontamination } \\
\text { activities }\end{array}$ & $1,219 \mathrm{E}-06$ & $7,3 \mathrm{E}-07$ & $4 \mathrm{E}-06$ & $3 \mathrm{E}-06$ & $2,96 \mathrm{E}-06$ & $2,4 \mathrm{E}-06$ & $8,2 \mathrm{E}-07$ \\
\hline F Construction & $3,929 \mathrm{E}-05$ & $2,3 \mathrm{E}-05$ & $1 \mathrm{E}-04$ & 0,0002 & $5,65 \mathrm{E}-05$ & 0,00013 & 2,3E-05 \\
\hline $\begin{array}{l}\text { G Wholesale and retail trading; keeping } \\
\text { and repairing of cars and motocars }\end{array}$ & $2,002 \mathrm{E}-05$ & $1,7 \mathrm{E}-05$ & 7E-05 & $4 \mathrm{E}-05$ & 0,000148 & $3,7 \mathrm{E}-05$ & $2,2 \mathrm{E}-05$ \\
\hline H Transport and storing & $1,852 \mathrm{E}-05$ & $1,9 \mathrm{E}-06$ & $1 \mathrm{E}-05$ & $2 \mathrm{E}-05$ & $3,82 \mathrm{E}-05$ & $7,1 \mathrm{E}-06$ & $2,1 \mathrm{E}-06$ \\
\hline $\begin{array}{l}\text { I Accomodation and public nourisment } \\
\text { activities }\end{array}$ & $1,7 \mathrm{E}-07$ & $3,7 \mathrm{E}-08$ & $3 \mathrm{E}-07$ & $6 \mathrm{E}-07$ & $1,17 \mathrm{E}-06$ & $7,8 \mathrm{E}-07$ & $7,2 \mathrm{E}-08$ \\
\hline J Information and communication & $1,151 \mathrm{E}-05$ & $1 \mathrm{E}-06$ & 7E-06 & $3 \mathrm{E}-06$ & 9,89E-06 & $2,2 \mathrm{E}-06$ & $7,6 \mathrm{E}-07$ \\
\hline K Financial and asurance activities & $5,477 \mathrm{E}-07$ & $2,4 \mathrm{E}-06$ & $1 \mathrm{E}-06$ & $4 \mathrm{E}-07$ & $6,36 \mathrm{E}-07$ & $2,7 \mathrm{E}-07$ & $1,7 \mathrm{E}-07$ \\
\hline L Estate tranzactions & $9,518 \mathrm{E}-06$ & $2 \mathrm{E}-06$ & $6 \mathrm{E}-05$ & $1 \mathrm{E}-05$ & $3,8 \mathrm{E}-05$ & $1,1 \mathrm{E}-05$ & $1,1 \mathrm{E}-06$ \\
\hline $\begin{array}{l}\text { M Professional, scientific and } \\
\text { technical activities }\end{array}$ & $1,69 \mathrm{E}-07$ & $1,6 \mathrm{E}-08$ & 0 & $6 \mathrm{E}-06$ & $2,85 \mathrm{E}-07$ & $3,8 \mathrm{E}-07$ & $1,4 \mathrm{E}-07$ \\
\hline $\begin{array}{l}\text { N Activități de servicii Administration } \\
\text { servivies and support servicies }\end{array}$ & $1,32 \mathrm{E}-06$ & $5,5 \mathrm{E}-07$ & $4 \mathrm{E}-06$ & $1 \mathrm{E}-06$ & 4,46E-06 & $3,2 \mathrm{E}-06$ & $1,7 \mathrm{E}-07$ \\
\hline P Education & $1,972 \mathrm{E}-05$ & $2,8 \mathrm{E}-06$ & $5 \mathrm{E}-06$ & $6 \mathrm{E}-06$ & $5,3 \mathrm{E}-05$ & $4,3 \mathrm{E}-05$ & $1,1 \mathrm{E}-05$ \\
\hline Q Health and social assistance & 0 & 0 & 0 & 0 & 0 & 0 & 0,00045 \\
\hline
\end{tabular}

Source: Author`s calculations.

Calculations results, depicted in the considered table, also demonstrate considerable GDP growth during the examined years under sufficient decreasing of the energy resources weight of the energy industry.

For the dynamic model as well as for the static model, necessary data were gathered and processed. So the data from Statistic Yearbooks for the years 2000-2015 were selected, and were completed by specific features for dynamic model. Because since year 2015, Moldovan statistics has been changed in accordance with industrial structure of the European Union, the 19 industries structure instead of 23 was adopted. The new industry structure also looks like in table 9.

Examined model offered many opportunities for diverse scenario elaboration and solving both in order to modify rates of growth of the industries produce volumes, and to modify technology matrix structure, and also to increase profitability of the productive industries. Simulations calculations results obtained can be useful for decision making person's in formulating development polices in 
particular at economy as a whole level and at the sector level in special.

3. Markov chains and exchange matrix for the Republic of Moldova

Let come back to the input-output model with 16 aggregate industries which described economy of the Republic of Moldova. Industry $i$ necessitates the quantity $0 \leq a_{i j} \leq 1$ of goods (in money value) from the industry $j$ in one lei value. Let $A$ be the direct material expenditure coefficients matrix with its elements $a_{i j}, 16 \leq i, j \leq 16$. Let the demand for final consumption be vector $y=\left(y_{1}, y_{2}, \ldots, y_{n}\right)$. We will make up Markov chain taking as the states technology vectors in correspondence with examined industries, and as a transition probabilities $a_{i j}$ elements. It is well known that the direct expenditure coefficients matrix (technology coefficients matrix) has satisfied conditions $0 \leq a_{i j} \leq 1,1 \leq i, j \leq n$ and line sum is equal to $\sum_{j=1}^{n} a_{i j}<1,1 \leq i \leq n$ and is strictly less than one.

Further transition - probabilities matrix will be constructed for the exchange matrix in the input-output model. For this purposes 16x16 exchange matrixes for Republic of Moldova (year 2014) were considered.

We examine stochastic matrix, which has nonnegative elements, each column of it sums to one. Economically, the system can be interpreted either as one in which there is no demand or one in which demand is considered as an industry which consumes all its own output.

Such matrices also arise in the analysis of finite Markov chains: stochastic processes in which the probability of being in a particular state at any step depends only on the state occupied at the previous step. More exactly, consider repetitive trials of an experiment with a finite number of possible outcomes $S_{1}, S_{2}, \ldots, S_{n}$. The sequence of outcomes is a Markov chain if there is a set of $n^{2}$ numbers $p_{i j}$ such that the conditional probability of outcome $S_{j}$ on any trial, given outcome $S_{i}$ on the previous trial, is $p_{i j}$; that is $p_{i j}=\operatorname{Pr}\left(S_{j}\right.$ on trial $k+1 \mid S_{i}$ on trial $\left.k\right), \quad 1 \leq i, j \leq n, k=1,2, \ldots$

The transition probabilities $p_{i j}$ can be arranged in a stochastic matrix as follows:

$$
P=\left[\begin{array}{cccc}
p_{11} & p_{21} & \ldots & p_{n 1} \\
p_{12} & p_{22} & \ldots & p_{n 2} \\
& \ldots & \\
p_{1 n} & p_{2 n} & \ldots & p_{n n}
\end{array}\right] .
$$

Let $p_{i}^{(k)}$ be the probability that the outcome on the $k$ th trial $S_{i}$ and $p^{(k)}=\left(p_{1}^{(k)}, p_{2}^{(k)}, \ldots p_{n}^{(k)}\right)^{T}$ be the associated probability distribution vector. Then, for Markov processes, it is true that $p^{(k+1)}=P p^{(k)}, k=1,2, \ldots$ Thus a Markov chain is completely characterized by its transition matrix $P$ and an initial probability distribution $p^{(0)}$ in the sense that $p^{(k)}=P^{k} p^{(0)}, k=1,2, \ldots$

In many applications of Markov processes, one is interested in the existence of equilibrium probability distributions; that is, vector $p$ such that $p=P p$. For example, if some positive power of $P$ is strictly positive then it can shown that there is a unique strictly positive distribution $p$ so that

$\lim _{k \rightarrow \infty} P^{k} p^{(0)}=p$ for any initial distribution $p^{(0)}$.

The existence of equilibrium distribution vectors can be proven using the Brower Fixed Point Theorem.

If $s$ is the set of all probability distributions, then $s$ forms the standard $(n-1) \operatorname{simplex}$ in $R^{n}$ and for $p$ in $s$, we have:

$$
\sum_{i}(P p)_{i}=\sum_{i} \sum_{j}\left(p_{i j} p_{i}\right)=\sum_{i} \sum_{j} p_{j i} p_{i}=\sum_{j} p_{j} \sum_{i} p_{j i}=\sum_{j} p_{j}=1,
$$


so that $P p$ also lies in $s$. Thus, we can view $P$ as a linear transformation from $s$ to itself. Since $P$ is continuous.

We can consider exchange matrix $A$ as the transition matrix of a Markov chain provided only normalized price vector s productive whose components sum to one.

In the open model for an economy some output is accounted for by consumer demand. Every closed model may be considered as an open model too. In terms of matrix $A$, this means that some columns may sum to less then 1 . The system, or the matrix $A$, is productive if there is a nonnegative vector $X$ (output)such that $X \geq A X$. The vector $X$ is a production vector.

Theorem. A substochastic matrix $A$ is productive if and only if $I-A$ is nonsingular.

Corollary If $A$ is substochastic matrix, then the equation $(I-A) X=D$ has a nonnegative solution if $D \geq 0$; a positive solution if $D>0$; a strictly positive solution if $D>0$. In the transition matrix of the Markov chain, sum over its columns is equal to one. In order to satisfy this condition by the exchange matrix $A$, we proceed in the following manner. An absorbent state 0 , denoted as $a_{i 0}=1-\sum a_{i j}$ is added to exchange matrix $A$, obtaining the new matrix $A^{\prime}$, line sum over every line be equal to 1 .

$$
A^{\prime}=\left[\begin{array}{llllll}
a_{11} & a_{12} & \cdots & a_{1 n} & 1-\sum_{j} a_{1 j} & \\
a_{21} & a_{22} & \cdots & a_{2 n} & 1-\sum_{j} a_{2 j} & \mid \\
& \cdots & \cdots & \cdots & \cdots & \\
a_{n 1} & a_{12} & \cdots & a_{n n} & 1-\sum_{j} a_{n j} & \vdots \\
0 & 0 & \cdots & 0 & 1 & \vdots
\end{array}\right] .
$$

For columns sum to be equal to 1 , it is needed to transpose the matrix $A^{\prime}$ and so transition matrix $P$, is obtained, in which column sum is equal to one.

$$
P=\left\{\begin{array}{llllll}
a_{11} & a_{21} & \ldots & a_{1 n} & 0 & \\
a_{12} & a_{22} & \ldots & a_{2 n} & 0 & \\
& \ldots & \ldots & \ldots & \ldots & \\
a_{1 n} & a_{2 n} & \ldots & a_{n n} & 0 & \\
1-\sum_{j} a_{1 j} & 1-\sum_{j} a_{2 j} \ldots & 1-\sum_{j} a_{n j} & 1
\end{array}\right]
$$

Principal cofactor of the matrix $P$ is equal to $P_{n n}=(-1)^{(n+n)}|A(n, n)|$, and $|P|=1 * P n n=|A|$. Suppose that $X$ is the production volume vector in the year 2015, and $Y$ is the final demand vector in the same year (both normalized to one), then expression for the Gross Domestic Product is $X-A X=Y$, while vector $t$ is absorbtion expectation time, $t=N c$, where $N=(I-A)^{-1}$ and $c=(1,1, \ldots, 1)$ is the ${ }_{n}$ - dimensional vector $t=(3,1,1,9,2,4,4,3,1,4,2,1,2,1,1,1,2,2,2,1)$. $\operatorname{det}(I-A)=0,097185947 \quad$, then inverse matrix $(I-A)^{-1}$ exists, and matrix $A$ is productive.

There is not any positive power of $P$ which is strictly positive for the matrix $A$. Right now we calculated a power of the matrix $A$ equal to 15 , for which $p^{(15)}=P^{15} p^{(0)} \cong 0$, then there is a unique strictly positive distribution $p=0$ so that

$$
\lim _{k \rightarrow \infty} P^{k} p^{(0)}=p \text { for the initial distribution } p^{(0)}=X \text {, normalised to one . So, beginning from }
$$

the initial state $X_{2015}$ and technology matrix $A_{2015}$ examined economy has been tendedto collapse. 


\subsection{Conclusions}

Markov chain approach to the input-output models study was examined. Input-output table for year 2015 in 16 structure has been transformed into transition matrix by adding one additional column and then transposing it. After transposing transformed matrix became transition one with columns sum equal to 1 . Applying known theory about Markov chain to the considered matrix, it was possible to study stability problem and time of transition from one state to another. So, effectuated calculations demonstrates that, it is strictly necessary to modernize the economy by implementing new contemporary technologies, the faster the better, because economy collapse can be happened in the following ten years.

\section{General conclusions}

Presented overview of the input-output models application to the concrete economy in transition like Moldovan economy, has demonstrated usefulness of this tool for empirical study. RAS method for input-output table balancing has been applied and realized as software program. Both static and dynamic optimization models can be implicated to elaboration of the diverse scenarios and their analysis. New technology proposed for implementation could be tested before it. Direct expenditure coefficients investment matrix has been constructed starting with settled down industries growth rate investment figures and then based on it, dynamic optimization model was solved using Solver procedure. The same procedure was also used for solving static and dynamic optimization models. Assumption about constancy of both technological and investment matrixes was made in order to effectuate calculation in time. This assumption was justified actually by small changes in time of technological and investment coefficients. Markov chain application to the input-output model treatment, appear to be very useful from the stability problem point of view. All together, examined methods are recommended for policy makers in order to consult alternative opinion when decisions are taking.

\section{REFERENCES}

1. LEONTIEF, Wassily. Input-Output Economics. Oxford: Oxford University Press, 1966. 257 p.

2. LEONTIEF, Wassily, FORD, Daniel. Air Pollution and Economic Structure: Empirical Results of Input-Output Computations. In: Input-output techniques 1971: Proceedings of the Fifth International Conference on Input-Output Techniques, january 1971. Amsterdam: North-Holland Publ. Co., 1972, pp. 9-30. ISBN 072043064X.

3. FONTILA, Emilio. Leontief and the Future of the World Economy. 2000, august. [Accesat 18.11.2018]. Disponibil: https://www.iioa.org/conferences/13th/files/Fontela_Leontief.pdf

4. PETERSON, Bruce, OLINICK, Michael. Leontief models, Markov chains, substochastic matrices, and positive solutions of matrix equations. In: Mathematical modeling. 1982, vol. 3, pp. 221-239. [Accesat 21.02.2018]. Disponibil: https://core.ac.uk/download/pdf/81156007.pdf

5. TRINH,Bui, PHONG, N.V. A Short Note on RAS Method. In: Advances in Management \& Applied Economics. 2013, vol. 3, no. 4, pp. 133-137. ISSN 1792-7544, ISSN 1792-7552. [Accesat 16.12.2018]. Disponibil: https://www.researchgate.net/publication/308018908_A_Short_Note_on_RAS_Method

6. DIACONOVA, M., NAVAL, Elvira. Modelul interramural de prognoză a dezvoltării economiei naţionale. In: Buletinul Academiei de Ştiințe a Republicii Moldova. Matematica. 1999, nr. 3 (31), 1999, pp. 51-60. ISSN 1024-7696.

7. NAVAL, Elvira, GHEREG, Veronica. Input-Output model for Republic of Moldova. In: Proceedings of The 4th Conference of Mathematical Society of the Republic of Moldova, june 28-july 22017. [Accesat 15.11.2018]. Disponibil: http://dspace.usm.md:8080/xmlui/bitstream/handle/123456789/1665/425_428_InputOutput\%20model\%20for\%20Republic\%20of\%20Moldova.pdf?sequence=1\&isAllowed=y

8. Biroul Naţional de Statistică. [Accesat 21.02.2018]. Disponibil: http://www.statistica.md

9. NAVAL, Elvira. Modelul interramural static de optimizare în condiţiile modificărilor structurale. In: Creșterea Economică în condiţiile globalizării: modele de dezvoltare durabilă: conferinţa internaţonală ştiinţifico-practică, 12-13 octombrie 2017. Ediţia a XII-a. Chişinău: INCE, 2017, vol. 1, pp. 47-52. ISBN 978-9975-3171-1-5. 
10. NAVAL, Elvira. Elaborarea modelelor economice în baza balanţelor interramurale. In: Akademos. 2017, nr. 2 (45), pp. 27-32. ISSN 1857-0461.

11. NAVAL, Elvira, GHEREG, Veronica. Modelul dinamic de optimizare pentru Republica Moldova. In: Modelare matematică, optimizare şi tehnologii informaţionale: conferinţa internaţională, 12-16 noiembriee 2018. Ediţia a V-a. Chişinău, 2018, pp. 146-151. ISBN 978-9975-62-421-3.

12. KUN, Dong. The dynamic Optimization Model of Industrial Structure with Energy-saving and Emission-reducing Constraint. In: Journal of Sustainable Development. 2008, vol.1, no. 2, july. [Accesat 17.12.2018]. Disponibil: https://pdfs.semanticscholar.org/e11d/95545f6b9702d6dc235ff0a697e88fdceb96.pdf

13. BUI, Trinh, NGUYEN VIET, P.A Short Note on RAS Method. In: Advances in Management \& Applied Economics. 2013, vol. 3, no. 4, pp. 133-137. ISSN 1792-7544.

14. PESCHEK, W. Input-Output Models and Markov Chain. [Accesat 26.10.2018]. Disponibil: https://businessdocbox.com/amp/80612155-Marketing/Input-output-models-and-markovchains.html

15. KEMENY, Laurie Snell, JOHN, G. Finite Markov Chains. Management Mathematics for European Schools. 1963. [Accesat 12.11.2018]. Disponibil: https://www.amazon.com/Finite-MarkovChains-Laurie-Kemeny/dp/B000KYES00

16. GRINSTEAD, Charles, SNELL, J. Laurie. Introduction to Probability. Chapter 11. American Mathematical Society. 1997. [Accesat 26.10.2018]. Disponibil: http://mathsdemo.cf.ac.uk/maths/resources/Probability_Answers.pdf

17. KAKUTANI, Shizuo. A generalization of Brower's fixed point theorem. In: Duke Mathematical Journal. 1941, vol. 8 (3), pp. 413-589.

18. DUCHIN, Faye, STEENGE, Albert E. Mathematical Models in Input-Output Economics. Rensselaer Working Papers in Economics. 2007, april. [Accesat 21.02.2019]. Disponibil: https://www.researchgate.net/publication/24125153_Mathematical_Models_in_InputOutput_Economics

19. ARROW, K.J. Alternative Proof of the Substitution Theorem for Leontief Models in the General Case. In: T.C. KOOPMANS (ed.) Activity Analysis of Production and Allocation. New York, 1951, pp. 155-164.

Recommended for publication: 10. 06.2019 